\title{
Financial Analysis of Solar Water Heating Systems during the Depression: Case Study of Greece
}

\author{
Jacob G. Fantidis, Dimitrios V. Bandekas, Constantinos Potolias, Nick Vordos, Kostas Karakoulidis
}

Kavala Institute of Technology

St. Lukas, Kavala 65404, Greece

e-mail: fantidis@yahoo.com,dbandek@teikav.edu.gr,cpotolias@yahoo.gr,nvordos@teikav.edu.gr,

karakoul@teikav.edu.gr

crossref http://dx.doi.org/10.5755/j01.ee.23.1.1222

The use of solar thermal collectors is an economic alternative for water heating. In Greece more than 4 million $\mathrm{m}^{2}$ of collector area has been installed; however, the financial and economic crisis has dealt the solar thermal market a heavy blow. The aim of the paper is twofold: firstly, to present the new legislations and combined efforts taken by the government in order to give the solar thermal market a boost; secondly, to evaluate the effect of these efforts and calculate the new financial data from the citizens. For the promotion of solar water heaters, new legislations and concerted efforts are taken by the government. The effect of the new incentive program on the payback time of a typical glazed solar hot water system in Greece was investigated in this work. Long-term meteorological data from 47 stations are analyzed in order to evaluate the potential of solar water heater application at each site in Greece. The RETScreen software was used to predict the financial viability and the green house gas emissions reductions. The economical indicators showed that Tymbakion was the best site and Ioannina the worst. From the environmental point of view, it was found that on an average an approximate quantity of 1.47 ton of green house gases can be avoided entering into the local atmosphere each year.

Keywords: Solar water heaters, Renewable energy, Payback period, GHG Emissions, Greece.

\section{Introduction}

The idea of using the sun to heat water is not a new concept. Black painted water tanks were used as solar water heaters more than 1000 years ago. The sun is clean, inexhaustible, environmentally friendly, and sustainable source of energy. According to Resch et al. the global theoretical potential of solar energy was estimated at $3900000 \mathrm{EJ}$, however, the technical potential of solar energy is 1600 EJ (Resch et al., 2008) . Solar water heating technology has greatly improved during the past century. Today, only in the European Union there are more than 35.9 million $\mathrm{m}^{2}$ of installed solar collectors (EurObserv'ER, 2011).Solar energy on water heating has proved reliable and economical. Greece is located in SE Mediterranean area with an affluent and reliable supply of solar energy, even during the winter. The entire Greek territory is characterized by high solar irradiance, so the annual solar energy at horizontal plane varies between $1450 \mathrm{kWh} / \mathrm{m}^{2}$ and $1800 \mathrm{kWh} / \mathrm{m}^{2}$ (Figure 1) (PVGIS, 2008). Considering solar radiation and many incentives form the Greek governments, it is not a surprise that Greece occupies the third position in the European Union market of domestic solar collectors. In the present study the project takes for granted a typical glazed liquid flat-plate collector, which are commonly used as domestic hot water systems (DHWS) to calculate the financial viability and the emission reduction due to the DHWS. 47 locations in Greece are considered, both the economic analysis and the environmental considerations calculated using the RETScreen software. The RETScreen Clean Energy Project Analysis Software (RETScreen, 2011) is an advanced mathematical model to evaluate the energy production and savings costs, emission reductions, financial viability and risk for various types of Renewable-energy and Energyefficient Technologies.

\section{Case study (Greece)}

It is widely acknowledged that Greece possesses an excellent solar energy potential according to the existing long-term measurements, as presented in Figure 1.

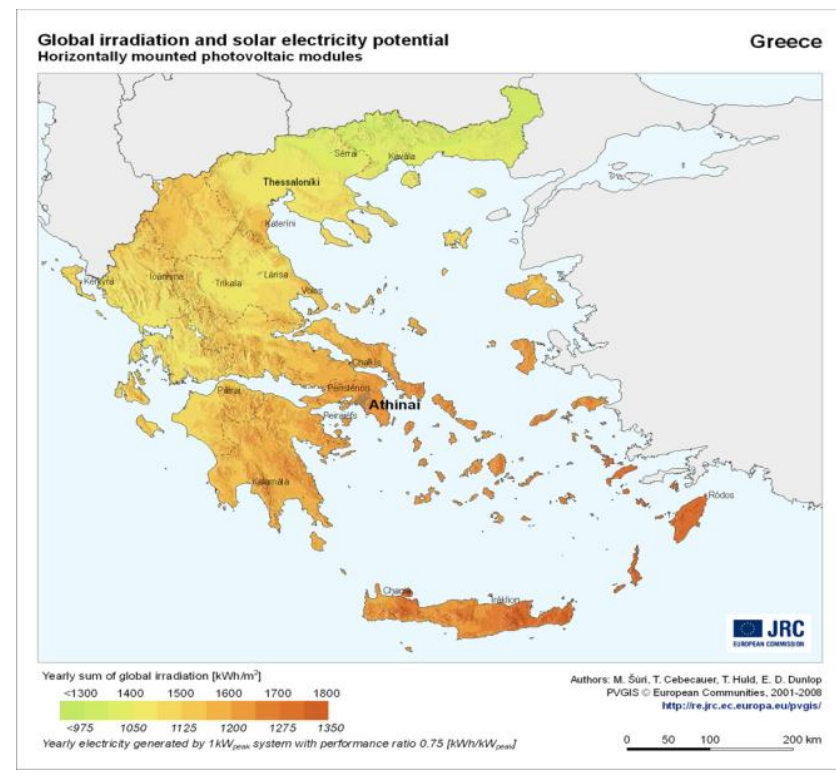

Figure 1. Global solar radiation in Greece 
The economic viability of solar water heating systems is an old subject for the Greek researchers (Panteliou et al., 1990), (Haralambopoulos, Paparsenos and Kovras, 1997), (Diakoulaki et al, 2001), (Argiriou \& Mirasgedis, 2003), (Kalogirou, 2009), (Tsilingiridis \& Martinopoulos, 2010) Kaldellis et al. (Kaldellis, El-Samani \& Koronakis, 2005), and Sidiras et al. (Sidiras \& Koukios, 2005) presented the feasibility analysis of domestic solar water heating systems and the effect of the payback time on the spectacular diffusion of solar hot water systems in Greece. In this job the financial study has been realized not only on the famous Greek islands but also in many areas in the north Greece where solar radiation is smaller and the weather is colder. In addition, all the new financial data owing to the financial crisis were considered.

Greece is one of the most successful countries worldwide in the use of solar thermal energy. For many years, the number of installed systems of solar collectors per capita has been the highest within Europe (ESTIF, 2003)In the European Union, in terms of installed capacity Germany is the pioneer in the solar thermal collector capacity (in $\mathrm{m}^{2}$ and in MWth) followed by Austria, Greece, Italy and Spain (Figure 2). However, if population numbers are considered Cyprus is the leader in front of Austria, Greece, Germany and Malta. The installed solar thermal collector in $\mathrm{m}^{2}$ and $\mathrm{kW}$ th per capita is given in Figure 3. From the results it is obvious that Greece is in the third position in the country ranking (EurObserv'ER, 2011).

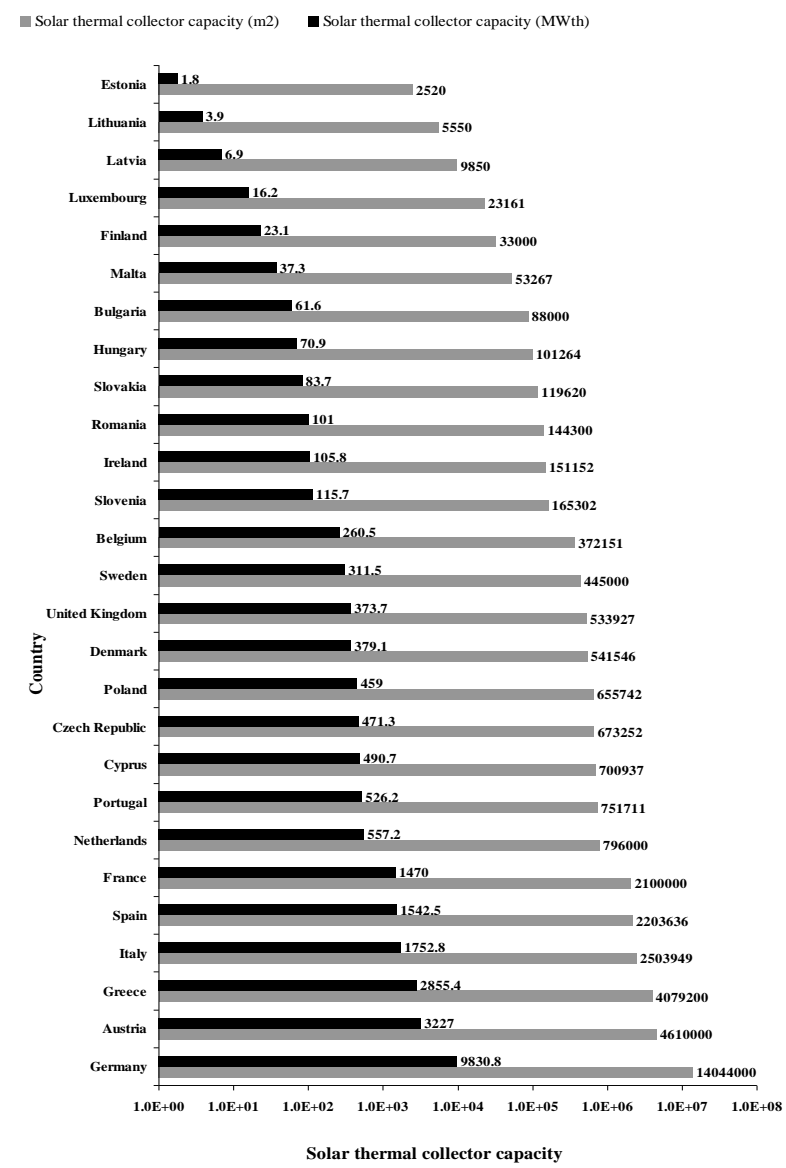

Figure 2. Total European Union solar thermal collector capacity installed by the end of 2010 (in $\mathrm{m} 2$ and in MWth)

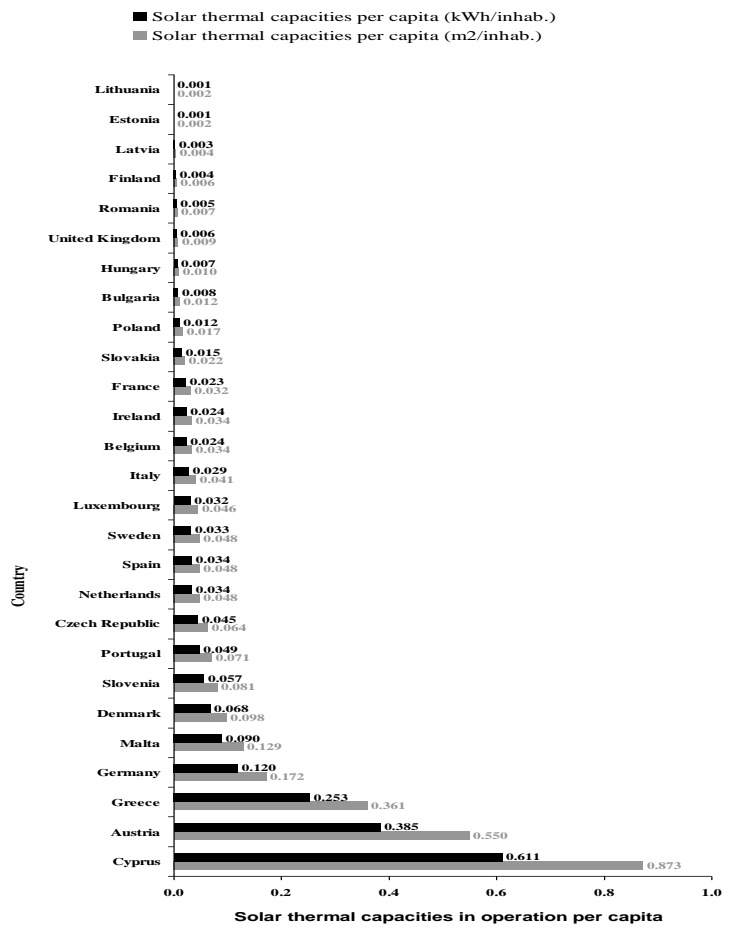

Figure 3. Solar thermal capacities capacity per $1000 \mathrm{EU}$ inhabitants in 2010

In order to promote solar hot water systems (SHWS) Greek governments have offered a number of significant incentives, for examples Laws 814/1978, 849/1978, $1116 / 1981,1262 / 82,1473 / 84,1892 / 1990,2364 / 95$ and 2601/98 support the DWHS market. More details there are on Ref. 13. However during the last 30 years the fiscal policy leads the country to the financial and economic crisis. This crisis has dealt the solar thermal market a heavy blow in Greece (which had 3500 jobs in 2008, and a major part of national output went for the export). According to the results (Figure 4), the market has dropped more than $30 \%$ in the last two years. In accordance with the EBHE (Greek Solar Industry Association) (ebhe, 2011) the main reason for this drop is that many families have decided to postpone their investments in a new solar hot water production system. In addition, the new bank loans are rather rarely owing to the fact that the cash flow of Greek banks is limited.

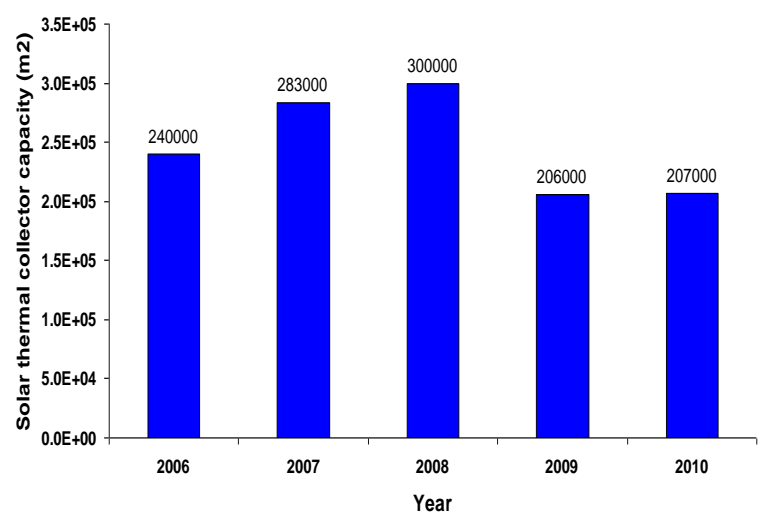

Figure 4. Solar thermal collector capacity installed in Greece from 2006 to $2010\left(\mathrm{~m}^{2}\right)$ 
In the effort to increase the sales of the DWHS two steps were taken from the relevant ministries. Firstly, Greek parliament passed a new Law (L3851/2010). According to the Law L3851/2010, since January 2011, all new (or redeveloped) buildings in Greece must cover at least $60 \%$ of their hot water requirements using solar energy (OJHR $3851,2010)$. However, the EBHE states that the new legislation will have limited effects initially because of the construction market decline.

Secondly, with the intention to achieve energy saving for each of the 13 Greek administrative regions, there exists one regional programme covering: thermal insulations, biomass heating systems, passive solar heating systems, ground-source heat pump systems and SHWS (exoikonomisi, 2011). According to the program (EXOIKONOMISI), for the buildings with building licence before 01-01-1990 there is grant (35\% for family income up to $60000 €$ or $15 \%$ for family income between $60000 €$ and $80000 €$ ) and flat loan for loan up to $15000 €$. In all circumstances the government has implemented an incentive system for private householders based on a tax deduction scheme of $20 \%$ of the installation cost. In any case, the tax relief cannot be above $700 €$.

\section{Climatic data}

The performance from a SHWS is strongly dependent on the climatic conditions and accurate weather data in a targeted location is essential. In this study the long term (1955 - 1997) meteorological parameters for each of the 47 considered sites in Greece are obtained from the Hellenic National Meteorological Service (HNMS, 2011) and from the Technical Chamber of Greece (OJHR, 407,2010). The average daily solar radiation and the average temperature at these locations are given in Table 1. The geography in terms of latitude, longitude and elevation from the sea level is also presented in the same table.

Table 1

Long-term daily mean values of global solar radiation and air temperatures for 47 locations in Greece

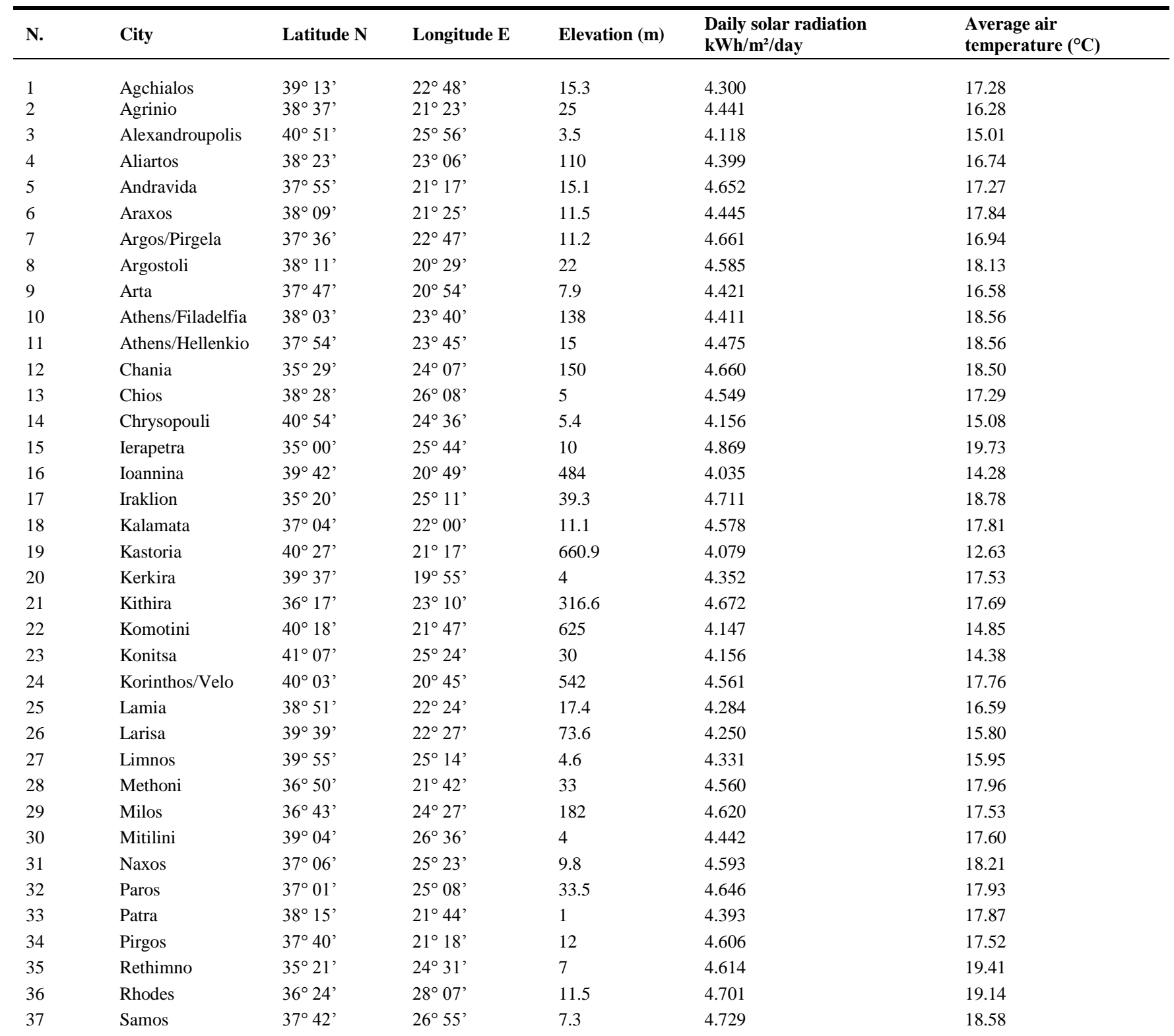


Jacob G. Fantidis, Dimitrios V. Bandekas, Constantinos Potolias, Nick Vordos, Kostas Karakoulidis. Financial Analysis of ...

\begin{tabular}{lllllll}
$\mathbf{N}$. & City & Latitude $\mathbf{N}$ & Longitude E & Elevation $(\mathbf{m})$ & Daily solar radiation & Average air \\
38 & Serres & $41^{\circ} 05^{\prime}$ & $23^{\circ} 34^{\prime}$ & 34.5 & 4.052 & 15.18 \\
39 & Siros & $37^{\circ} 25^{\prime}$ & $24^{\circ} 57^{\prime}$ & 72 & 4.625 & 18.71 \\
40 & Sitia & $35^{\circ} 12^{\prime}$ & $26^{\circ} 06^{\prime}$ & 115.6 & 4.741 & 18.77 \\
41 & Skiros & $38^{\circ} 54^{\prime}$ & $24^{\circ} 33^{\prime}$ & 17.9 & 4.315 & 17.24 \\
42 & Souda Bay & $35^{\circ} 33^{\prime}$ & $24^{\circ} 07^{\prime}$ & 151.6 & 4.728 & 18.19 \\
43 & Tanagra & $38^{\circ} 19^{\prime}$ & $23^{\circ} 33^{\prime}$ & 140.1 & 4.386 & 16.81 \\
44 & Thessaloniki & $40^{\circ} 31^{\prime}$ & $22^{\circ} 58^{\prime}$ & 4.8 & 4.008 & 15.80 \\
45 & Trikala Imathias & $40^{\circ} 36^{\prime}$ & $22^{\circ} 33^{\prime}$ & 0.8 & 4.074 & 15.15 \\
46 & Tymbakion & $35^{\circ} 00^{\prime}$ & $24^{\circ} 46^{\prime}$ & 6.7 & 4.887 & 19.04 \\
47 & Zakinthos & $39^{\circ} 10^{\prime}$ & $21^{\circ} 00^{\prime}$ & 10.5 & 4.376 & 17.93 \\
\hline
\end{tabular}

The long-term seasonal variation of global solar radiation and the air temperature $\left({ }^{\circ} \mathrm{C}\right)$ at 47 locations are shown in Figure 5 and Figure 6 correspondingly. From these figures, it is evident that higher values of radiation and higher temperatures were observed during summer months and lower in the Winter months. The study assumes a SWHS for a typical house with 4 occupants located for each of the 47 considered sites in Greece. The parameters of the investigated scenario are listed in Table 2 (Degelman, 2008).



Figure 5. Monthly variation of global radiation for 47 locations in Greece

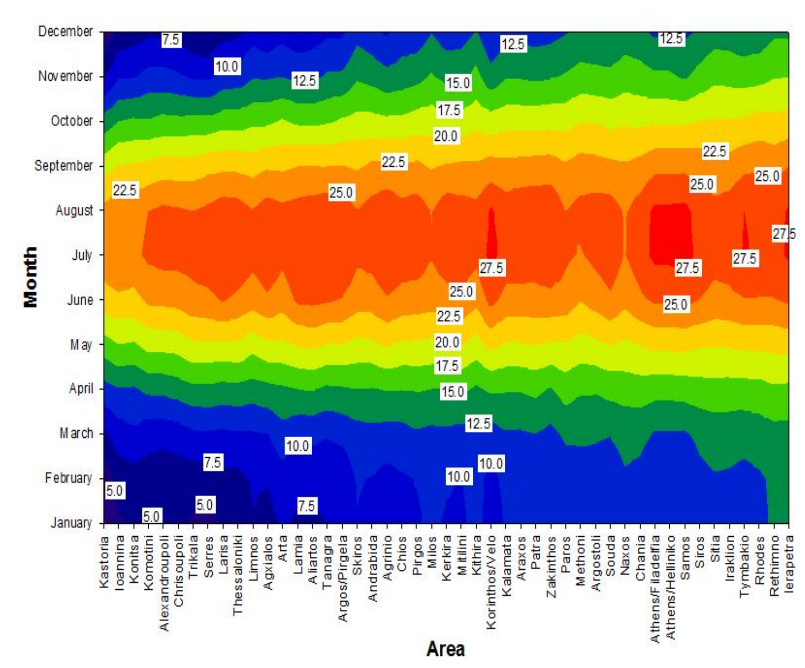

Figure 6. Monthly variation of air temperature for 47 locations in Greece
Table 2

\begin{tabular}{|c|c|}
\hline \multicolumn{2}{|c|}{ Input parameters for the RETScreen software } \\
\hline Parameter & Value \\
\hline Load type & House \\
\hline Occupant & 4 \\
\hline Occupancy rate & $90 \%$ \\
\hline Daily hot water use & $216 \mathrm{~L} / \mathrm{d}$ \\
\hline Temperature & $50^{\circ} \mathrm{C}$ \\
\hline Operating days per week & 7 days \\
\hline Water temperature - minimum & $7^{\circ} \mathrm{C}$ \\
\hline $\begin{array}{l}\text { Water temperature - maximum } \\
\text { Solar water heater }\end{array}$ & $29^{\circ} \mathrm{C}$ \\
\hline Type & Glazed \\
\hline Gross area per solar collector & $1.4 \mathrm{~m}^{2}$ \\
\hline Aperture area per solar collector & $1.3 \mathrm{~m}^{2}$ \\
\hline Fr (tau alpha) coefficient & 0.67 \\
\hline Fr UL coefficient & $4.35\left(\mathrm{~W} / \mathrm{m}^{2}\right) /{ }^{\circ} \mathrm{C}$ \\
\hline Temperature coefficient for Fr UL & $\left.0.013 \mathrm{~W} / \mathrm{m}^{2}\right) /{ }^{\circ} \mathrm{C}^{2}$ \\
\hline Number of collectors & 2 \\
\hline Solar collector area & $2.8 \mathrm{~m}^{2}$ \\
\hline Capacity & $1.82 \mathrm{~kW}$ \\
\hline Miscellaneous losses & $5 \%$ \\
\hline \multicolumn{2}{|l|}{ Balance of system \& miscellaneous } \\
\hline Storage capacity / solar collector area & $61.5 \mathrm{~L} / \mathrm{m}^{2}$ \\
\hline Storage capacity & $160 \mathrm{~L}$ \\
\hline Heat exchanger efficiency & $80 \%$ \\
\hline Miscellaneous losses & $5 \%$ \\
\hline Pump power / solar collector area & $5 \mathrm{~W} / \mathrm{m}^{2}$ \\
\hline Electricity rate & $0.078 € / \mathrm{kWh}$ \\
\hline GHG emission factor & $0.664 \mathrm{tCO} / \mathrm{MWh}$ \\
\hline \multicolumn{2}{|l|}{ Financial parameters } \\
\hline Inflation rate & $4 \%$ \\
\hline Project life & $20 \mathrm{yr}$ \\
\hline Debt ratio & $0 \%$ \\
\hline Initial costs & $1650 €$ \\
\hline Incentives and grants & $0 \%$ or $15 \%$ or $35 \%$ \\
\hline O\&M (savings) costs & $15 €$ \\
\hline
\end{tabular}




\section{RETScreen software}

The RETScreen Software Solar Water Heating Project Model was used to perform the economics feasibility and emission reductions (RETScreen, 2011). The RETScreen can be used to evaluate solar water heating projects, from small-scale domestic hot water applications and swimming pools, to large-scale industrial process hot water systems (Gastli \& Charabi 2011), (Houri, 2006).

The software contains six worksheets (Energy Model, Solar Resource and Heating Load Calculation, Cost Analysis, Greenhouse Gas Emission Reduction Analysis (GHG Analysis), Financial Summary and Sensitivity and Risk Analysis). The annual performance of a solar water heating system with a storage tank is dependent on system characteristics, solar radiation available, ambient air temperature and on heating load characteristics. The suggested values of daily hot water usage are derived from the tables published in the ASHRAE Applications Handbook (ASHRAE, 1995).

According to the Duffie and Beckman (Duffie \& Beckman, 1991) glazed collectors are described by the equation:

$$
\dot{Q}_{\text {coll }}=F_{R}(t a) G-F_{R} U_{L} \Delta T
$$

where $\dot{Q}_{\text {coll }}$ is the energy collected per unit collector area per unit time, $F_{R}$ is the collector's heat removal factor, $t$ is the transmittance of the cover, $\alpha$ is the shortwave absorptivity of the absorber, $G$ is the global incident solar radiation on the collector, $U_{L}$ is the overall heat loss coefficient of the collector, and $\Delta T$ is the temperature differential between the working fluid entering the collectors and outside.

The performance of service hot water systems with storage is calculated with the f-Chart method. The intention of the method is to compute the fraction of the hot water load $(f)$ that is provided by the solar heating system (solar fraction). The method enables the calculation of the monthly amount of energy delivered by hot water systems with storage, given monthly values of incident solar radiation, ambient temperature and load. The fraction $f$ of the monthly total load supplied by the solar water heating system is described by the equation:

$$
f=1.029 Y-0.065 X-0.245 Y^{2}+0.0018 X^{2}+0.0215 Y^{3}
$$

where $X$ and $Y$ are dimensionless parameters, which are defined as:

$$
\begin{aligned}
& X=\frac{A_{C} F_{R}^{\prime} U_{L}\left(T_{r e f}-T_{a}\right)}{L} \\
& Y=\frac{A_{C} F_{R}^{\prime} \overline{t a} H_{T} N}{L}
\end{aligned}
$$

$A_{c}$ is the collector area, $F_{R}^{\prime}$ is the modified collector heat removal factor, $T_{r e f}$ is an empirical reference temperature equal to $100^{\circ} \mathrm{C}, T_{a}$ is the monthly average ambient temperature, $L$ is the monthly total heating load, is the collector's monthly average transmittance-absorptance product, $H_{T}$ is the monthly average daily radiation incident on the collector surface per unit area, and $N$ is the number of days in the month (CEPA, 2005)

\section{Results and discussion}

Given the meteorological data at a certain site, the RETScreen calculates the pre-tax internal rate of return (IRR) on assets (\%), the simple and equity payback periods (years) and the GHG emission reduction. IRR represents the true interest yield provided by the project assets over its life before income tax, simple payback period represents the length of time that it takes for a proposed project to recoup its own initial cost, out of the income or savings it generates and equity period represents the length of time that it takes for the owner of a project to recoup its own initial investment out of the project cash flows generated. IRR, simple and equity payback periods calculated for every area for 3 cases, with $15 \%$ grant, with $35 \%$ grant and without incentives and grants.

IRR values at 47 locations are given in Figure 7. As seen from this figure, the IRR increases directly with the increase in global solar radiation value. The Aegean Archipelagos islands are the more attractive areas, contrarily the lowest values are obtained in the North Greece. Without grants the IIR fluctuates among 9 and 13 $\%$ with average value approximately $11.5 \%$. With $15 \%$ subsidy IRR varies from 11 up to $16.4 \%$ (with mean value about of $13.8 \%$ ) and for financing equal to $35 \%$ the IRR range from 14.9 up to $21.3 \%$. In all circumstances the maximum IRR is found at Tymbakion while the minimum IRR is found at Ioannina.

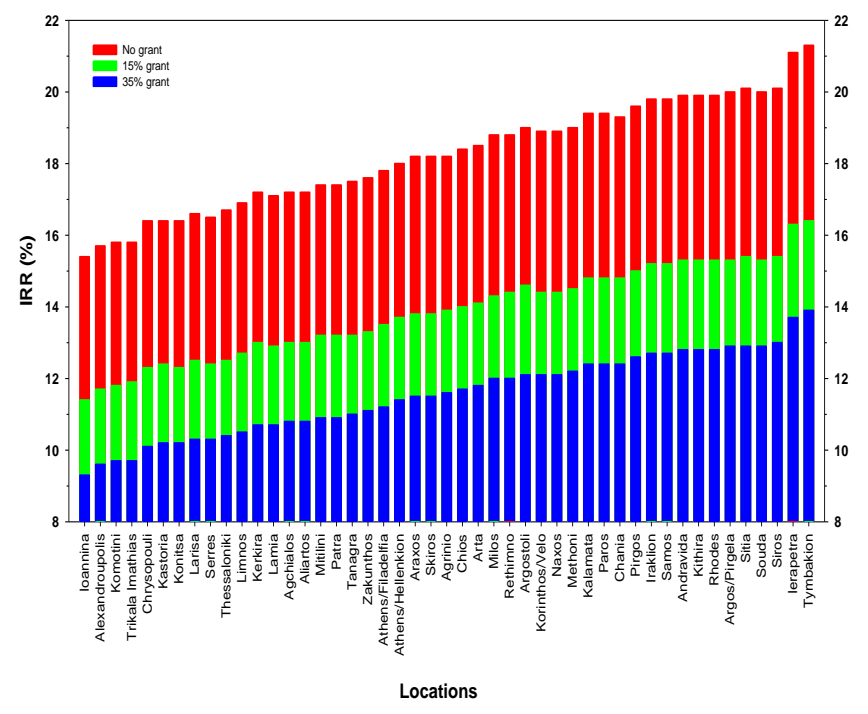

Figure 7. Internal rate of return values for 47 locations in Greece

Similarly, simple and equity payback periods are also mainly determined by the solar radiation. Both of these parameters are shown in Figure 8 and Figure 9 for all the locations. From these figures are obvious that areas with higher global solar radiation have the smallest payback periods. Minimum values of simple payback period of 5.7, 7.5 and 8.8 yr for grants $35 \%, 15 \%$ and $0 \%$ respectively, were found for Tymbakion. The corresponding maximum 
values of $8,10.5$ and $12.3 \mathrm{yr}$ were found at Ioannina. On an average, the simple payback period can be achieved in 6.8, 8.9 and $10.4 \mathrm{yr}$ at any location, respectively. Equity payback is a better time indicator of the project merits than the simple payback. The simple payback is useful, however, as a secondary indicator to indicate the level of risk of an investment. As regards the equity payback period, the minimums values were found at Tymbakion (7.4 yr without grants, $6.4 \mathrm{yr}$ for $15 \%$ grant and $5.1 \mathrm{yr}$ for $35 \%$ grant) while the maximum values were found at Ioannina (9.9 yr without grants, $8.6 \mathrm{yr}$ for $15 \%$ subsidy and 6.8 yr for $35 \%$ subsidy).

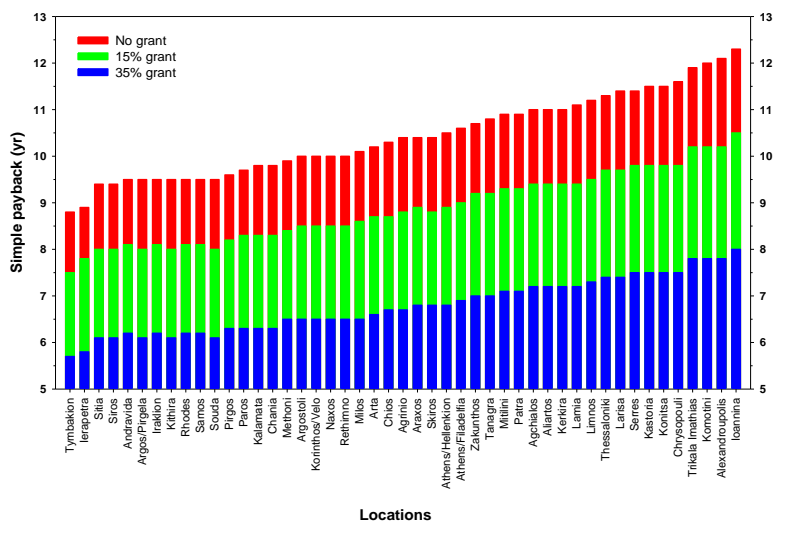

Figure 8. Simple payback period for 47 cities in Greece

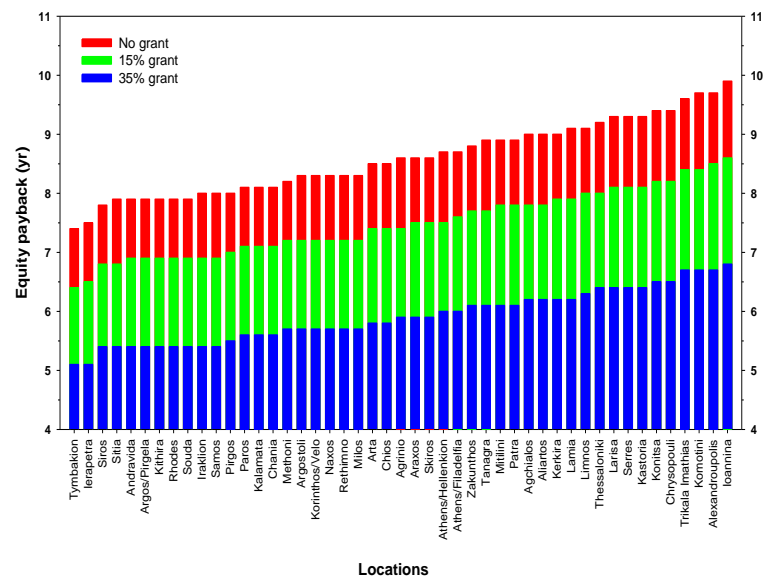

Figure 9. Equity payback period for 47 cities in Greece

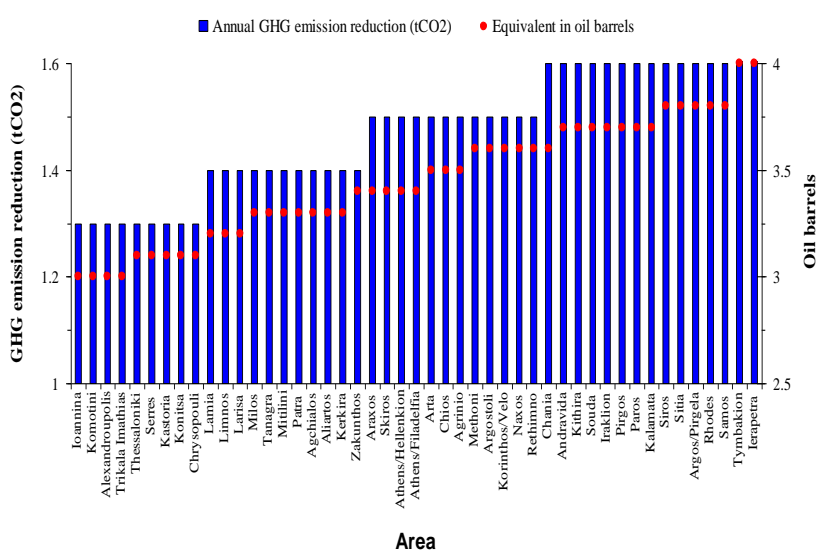

Figure 10. Green house gases reduction due usage of SWHS
The RETScreen is capable of estimating the amount of GHG which could be avoided as a result of usage of SWHS. The amount of GHG reduction and the equivalent in oil barrels for the 47 locations are presented in Figure 10. Based on Figure 10 the highest GHG emissions mitigation of 1.7 tons/year was observed at Ierapetra and Tymbakion. On an average more than 1.47 ton of green house gases each year can be avoided from entering into atmosphere from any location in the Greece from each SWHS

\section{Conclusions}

Greece has a high content of solar radiations all over the year and occupies the third position in the European Union market of domestic solar collectors. However many serious mistakes in fiscal policy lead the country to the financial and economic crisis. Despite the pecuniary problems, the Greek government tries to encourage the solar thermal market. For this direction there is a new incentive program for old houses and in the new buildings compulsory $60 \%$ of hot-water needs to be covered by solar thermal. The study carried out, aimed to present and evaluate, not only from economic view, the efforts from the Greek parliament. According to the new data this paper has investigated the financial prospects of using a SWHS in Greece. Using average daily meteorological data the study assumed a typical glazed SWHS at each of the 47 cities, to calculate the IRR, the simple payback period, the equity payback period and the potential emission reduction due to the SWHS.

Based on economical indicators, Tymbakion was found to be the best site for the installation of SWHS and Ioannina the worst. The mean value of IRR was found to be $11.6 \%, 13.9 \%$, and $18.2 \%$ for grant $0 \%, 15 \%$ and $35 \%$ respectively. Even if there aren't grants the minimum IRR value are bigger than $9.3 \%$. In all circumstances the simple payback period was smaller than $12.3 \mathrm{yr}$ while the equity payback period varied between 7.4 and $9.9 \mathrm{yr}$ in the case without grants. With $15 \%$ and $35 \%$ grants the maximum equity payback period is 8.6 and $6.8 \mathrm{yr}$ correspondingly. From environmental point of view, it was found that on an average an approximate quantity of 1.47 ton of green house gases can be avoided entering into the local atmosphere each year from a typical glazed SWHS in any part of the Greece.

Considering that the bank loan is limited, owing to the financial crisis, the new energy saving programme is expected to support not only the sales of the solar hot water systems but also to provide jobs on more than 3500 labourer. At the same time it helps in the energy saving of the country and reduces the electricity bill for thousands consumers. Last but not the least, the SWHS offer many environmental benefits to the Greek citizens. 


\section{References}

Argiriou, A. A., \& Mirasgedis, S., (2003). The Solar Thermal Market in Greece-Review and Perspectives. Renewable and Sustainable Energy Reviews, 7, 397-418.

ASHRAE (1995). Applications Handbook (SI) - Service Water Heating, American Society of Heating, Refrigerating, and Air- Conditioning Engineers, Inc., 1791 Tullie Circle, N.E., Atlanta, GA, 30329, USA.

CEPA (2005). Clean Energy Project Analysis. RETScreen ${ }^{\circledR}$ Engineering and Case Studies Textbook, Solar Water Heating Analysis Project Chapter. Third Edition, from: www.retscreen.net

Degelman, L. O. (2008). Calibrated Simulation of a Solar Hot Water System to Match Degraded Performance Over a 22Year Period Using Two Models, Building and Environment, 43, 628-637.

Diakoulaki, D., Zervos, A., Sarafidis, J., \& Mirasgedis, S. (2001). Cost Benefit Analysis for Solar Heating Systems. Energy Conversion and Management, 42, 1727-1739.

Duffie, J. A., \& Beckman, W. A. (1991). Solar Engineering of Thermal Processes, 2nd Edition, John Wiley \& Sons.

ESTIF European Solar Thermal Industry Federation, (2003). Sun in Action II - A Solar Thermal Strategy for Europe, Volume 2, The Solar Thermal Sector Country by Country, 21 National Reports.

EurObserv'ER, (2011). Solar Thermal and Concentrated Solar Power Barometer - EUROBSERV’ER - N 203 MAY 2011 (http://www.eurobserver.org/).

European Parliament. (2011). Available from: http://www.ebhe.gr/pages/english/role.htm

Gastli, A., \& Charabi, Y. (2011). Solar Water Heating Initiative in Oman Energy Saving and Carbon Credits. Renewable and Sustainable Energy Reviews, 15, 1851-1856.

Haralambopoulos, D., Paparsenos, G. F., \& Kovras, H. (1997). Assessing the economic aspects of solar hot water production in Greece. Renewable Energy, 11, 153-167.

Hellenic National Meteorological Service, (2011). from: (http://www.hnms.gr)

Houri, A. (2006). Solar water heating in Lebanon: Current status and future prospects. Renewable Energy, 31, 663-675.

Kaldellis, J. K., El-Samani, K., \& Koronakis, P. (2005). Feasibility Analysis of Domestic Solar Water Heating Systems in Greece. Renewable Energy 30, 659-682.

Kalogirou, S. (2009). Thermal Performance, Economic and Environmental Life Cycle Analysis of Thermosiphon Solar Water Heaters, Solar Energy, 83, 39-48.

Official Journal of the Hellenic Republic. (2010). 407/9.4.2010, KENAK. from: http://www.et.gr/search_publication

Official Journal of the Hellenic Republic. (2010). L3851/2010. from: http://www.et.gr/search_publication.

Panteliou S., Chondros T., Bouziotis G., \& Dimarogonas A. D. (1990). Reliability of hot Water Solar Systems in Greece, Solar Energy, 44, 305-313.

Papakostas K. T., Papageorgiou N. E., \& Sotiropoulos, B. A. (1995). Residential, Hot Water Use Patterns in Greece. Solar Energy, 54, 369-374.

Photovoltaic Geographical Information System (PVGIS), (2008). Available from http://re.jc.ec.europa.eu/pvgis/.

Resch, G., Held, A., Faber, T., Panzer, C., Toro, F., \& Haas, R. (2008). Potentials and Prospects for Renewable Energies at Global Scale. Energy Policy, 36, 4048-4056.

RETScreen International (2011). Renewable energy project analysis software. From: http://www.retscreen.net/

Sidiras, K. D., \& Koukios, G. E. (2005). The Effect of Payback Time on Solar Hot Water Systems Diffusion: the Case of Greece. Energy Conversion and Management, 46, 269-280.

Tsilingiridis, G., \& Martinopoulos, G. (2010). Thirty Years of Domestic Solar Hot Water Systems Use in Greece - Energy and Environmental Benefits - Future Perspectives. Renewable Energy, 35, 490-497.

Jacob G. Fantidis, Dimitrios V. Bandekas, Constantinos Potolias, Nick Vordos, Kostas Karakoulidis

Saulès vandens šildymo sistemų, ištikus depresijai finansinė analizė: Graikijos atvejis

Santrauka

Dabartiné situacija. Gerai žinoma, kad Graikijos saulès energijos potencialas pagal esamus ilgalaikius matavimus yra puikus: metinè saulès energija prilygsta $1800 \mathrm{kWh} \mathrm{m}^{2}$. Graikijos klimatas yra Viduržemio jūros, todèl vyrauja ilgos karštos sausos vasaros ir švelnios žiemos. Graikija yra kalnuota šalis su daugeliu išsiskirsčiusių salų. Tai sukuria mikroklimato ir vietinès įvairovès derinị. Pietinėje Graikijos dalyje, ypač Egèjaus archipegalo salose saulès radiacija aukščiausia, mažiau saulès yra šiaurinèje Graikijoje.

Po naftos krizès, 1970 m. Graikijos vyriausybė pateikè daugeli programų. Graikija tapo viena sėkmingiausių šaliu pasaulyje, kuri panaudoja saulès energiją. $2010 \mathrm{~m}$. pabaigoje Graikijoje buvo daugiau kaip $4 \mathrm{mln} . \mathrm{m}^{2}$ saulès kolektorių. Remiantis Graikijos saulès pramonès asociacijos duomenimis, saulès kolektorių skaičius vienam gyventojui ilgą laiką Europoje buvo aukščiausias. Šiandien Graikija užima trečią vietą Europos Sajungoje.

Saulès vandens šildymo sistemų galimybès nèra nauja tema mokslinèje literatūroje. Šis finansinès analizès tyrimas skirtas ne tik pietinès, bet ir Šiaurinès Graikijos padèčiai aptarti. Šioje Graikijos dalyje saulès mažiau, tačiau vanduo šaltesnis. Be to, buvo panaudoti nauji finansiniai duomenys, 
susiję su krize. Ištikus finansinei ir ekonominei krizei, Graikijoje reikèjo padidinti mokesčius ir sumažintu išlaidas. Pasikeite žmonių pragyvenimo lygis 2009-2010 m. saulès energijos rinka sumažèjo daugiau nei 30 proc., nors buvo didelis nuolaidos saulès energijos sistemoms.

2010 m. pab. vyriausybè prièmè naują istatymą, pagal kurị visi nauji arba rekonstruoti pastatai Graikijoje turi sudaryti mažiausiai 60 proc. pagal ju saulès energijos panaudojimą. Tačiau šias priemones apribojo rinkos kritimas statybu srityje. Buvo parengta ir energijos taupymo bei naujų energetikos rūšių panaudojimo programa. Pagal šią programą senesnių namų gyventojai gavo papildomas kompensacijas ir galimybę gauti paskolą. Šios lengvatos buvo skirtos daugiau nei 90 proc. Graikijos gyventoju.

Tyrimo tikslas. Svarbiausias šio darbo tyrimo tikslas - apskaičiuoti naujosios programos finansini efektą, kuris gaunamas dèl saulès karšto vandens sistemos Graikijoje. Šiame darbe panaudoti vidutiniai ilgalaikiai meteorologiniai duomenys (1955-1997) 47 Graikijos vietovèse. Ekonominè analizè ir aplinkos duomenys buvo gauti naudojantis kompiuterinèmis programomis. Švarios energijos projekto analizè yra pažangus matematinis metodas, skirtas švarios energijos technologiju galimybėms palengvinti. Tyrime nagrinėjamas tipinis skystujų plokštelių kolektorius, kuris paprastai naudojamas kaip buitinè karšto vandens sistema tipiniuose namuose. Metinė tokia karšto vandens saulès sistema priklauso nuo sistemos charakteristikų, saulès radiacijos, oro temperatūros ir apkrovos pobūdžio. Dienos karšto vandens sunaudojimo apimtis paimta iš spausdinamų duomenų. Pagal skelbiamus duomenis saulès kolektorių darbą galima pavaizduoti šia lygtimi:

$$
\dot{Q}_{\text {coll }}=F_{R}(\text { ta }) G-F_{R} U_{L} \Delta T ; \text { čia: }
$$

$\dot{Q}_{\text {coll }}$ - kolektoriaus energija per laiko vienetą; $F_{R}$ - kolektoriaus šilumos davimo veiksnys; $\mathrm{t}$ - dangčio pralaidumas; a - absorberio galimybės; G - globalusis saulès poveikis kolektoriui; $U_{L}$ - bendras kolektoriaus šilumos nuostolio koeficientas; $\Delta T$ - temperatūros skirtumas tarp ieinančio i kolektorių skysčio ir išorinès aplinkos.

Karšto vandens sistemų aptarnavimas su laikymu skaičiuojamas pagal $f$-lentelès metodą. Lygtis $f$, kuri parodo mènesio saulès energijos vandens šildymo sistemos apkrovimą, taip pat apskaičiuojama pagal specialią lygti.

Rezultatai ir išvados. Skaičiavimai, kurie buvo atlikti 47 vietovèse naudojant keturis parametrus; vidinis grižtamuju pajamų dydis (\%), grįžtamuju pajamu periodai ir duju sunaudojimo sumažèjimas. Grižtamosios pajamos yra pagrindinis projekto aspektas kolektoriaus gyvavimo laikotarpiu. Iš gautu pajamų ir santaupu prasideda projekto naudingumo efektas. Vidinès grižtamosios pajamos ir dujų sunaudojimas yra tam tikra prasme analogiški, todèl pietinès Graikijos vietovès yra patrauklesnès saulès energijos panaudojimo galimybėmis, o šiltojo periodo nauda atitinka saulès radiacijos vertę.

Graikija, kurios saulès energijos potencialas didelis apskritus metus ir kuri užima trečią vietą Europos Sajungos rinkoje pagal saulès kolektoriu panaudojimą, turi problemų finansinèje politikoje. Tai skatina finansinę ir ekonominę krizę. Nepaisant to, Graikijos vyriausybė skatina saulès energijos panaudojimą plečiant šios energijos rinką. Remiantis naujai pateikta programa, 60 proc. karštas vanduo tiek seniems, tiek naujiems namams turi būti tiekiamas panaudojant saulès energiją. Šio tyrimo tikslas - pateikti ir ịvertinti šias pastangas ne tik ekonominiu požiūriu.

Remiantis ekonominiais rodikliais Tymbakion sritis buvo įvertinta kaip geriausia vieta taisant saulès radiacijos energijos ịrenginius. Mažiausia irenginiu verte yra 11,6 proc., 13,9 proc., 18,2 proc. esant dotacijai 0 proc., 15 proc. ir 35 proc. atitinkamai. Net jeigu nėra dotaciju, minimali verte yra didesnè nei 9,3 proc. Aplinkos požiūriu buvo pastebèta, kad galima mažiau naudoti dujas ir kitose srityse.

Kadangi banko paskolos yra ribotos dèl finansinès krizès, naujoji energijos taupymo programa turètu remti ne tik saulès energijos karšto vandens sistemas, bet ir sukurti naujas darbo vietas daugiau nei 3500 darbuotojų. Be to, tai padètų taupyti šalies energetinius resursus ir sumažinti elektros mokesčius tūkstančiams vartotojų. Reikètų pabrěžti ir aplinkos saugojimo naudą Graikijos gyventojams. Todèl vandens šildymas naudojant saulès energiją yra patikimas ir ekonomiškas.

Raktažodžiai: saulès energijos vandens šildytuvai, atsinaujinusi energija, fondo gražos periodas, Graikija, saulès energijos misija.

The article has been reviewed.

Received in August, 2011; accepted in February, 2012. 